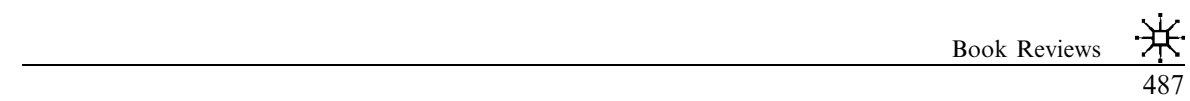

'materialist philosophy', and the paradoxical status of Marx's philosophy, but his investigations into the 'conjuncture' and the nature of the event as well. The texts collected in the Philosophy of the Encounter make it possible to excavate the philosophical problems and provocations underlying the edifices of Althusser's all too familiar assertions. The problems that Althusser deals with: the relation between thought and material reality, and the nature of the event, of radical change, remain absolutely contemporary.

Jason Read

University of Southern Maine, Portland, USA

\title{
Out of this World: Deleuze and the Philosophy of Creation
}

Peter Hallward

Verso, London and New York, 2006, 199pp.

ISBN: 10184467 5556/13: 9781844675555.

Contemporary Political Theory (2007) 6, 487-491. doi:10.1057/palgrave.cpt.9300311

It is beyond question, I think, that Deleuze is one of the most remarkable philosophers of the post-war period. And yet, in spite of the ever-growing literature on him, one has the distinct impression that very few people have any real clue as to the kind of philosopher Deleuze is. Peter Hallward's book goes a long way towards making a genuine comprehension of Deleuze's philosophy possible, and in this respect it is a significant achievement (forthcoming studies by Christian Kerslake and Daniel Smith will also do much to improve the quality of our understanding and reception of his work). However, on account of the fact that Hallward feels little affinity for Deleuze's philosophical project, anyone looking for an adequate and genuinely incisive assessment will be disappointed. Hallward is too distant from Deleuze's project and the thinkers that provide it with its inspiration to make this possible. There are two widespread misconceptions of Deleuze, and Hallward's study helps to correct both. The first is that Deleuze is first and foremost a Nietzschean thinker. While Deleuze published in 1962 a fine, if tendentious and one-sided study of Nietzsche, there are core elements of Nietzsche's project that never figure in Deleuze's writings. As Hallward shows, Deleuze's fundamental inspiration in fact comes from two main sources and influences: Spinoza and Bergson. The second misconception is that Deleuze belongs to the so-called post-structuralist 
and post-modern group of thinkers that emerged in France in the 1960s. But as Hallward points out, Deleuze is not an anti-foundational philosopher. His conception of philosophy has too many classical and traditional elements to it for it to be assimilated to post-modern thought, including a concern with discerning the 'ultimate nature of reality' and a preoccupation with the questions that have guided philosophy from Plato through to Descartes and Hegel, such as 'how does thought think?' and 'what is being?' (p. 134).

So, just what kind of philosopher was Deleuze? Hallward has devoted his book essentially to clarifying and illuminating this issue. His argument is that Deleuze is a visionary metaphysician - like Spinoza and Bergson in this regard - who develops a philosophy of creation centred on the conception of the infinite creative power of an immanent God. In some respects this makes Deleuze an heir to the spiritualist tradition within French philosophy he is most certainly not a materialist of any recognizable description, which is another widespread misconception. Hallward is perhaps closest to the mark when he describes Deleuze's thinking as a 'rationalist naturalism' that 'affirms the immediate... positivity of nature as production or process' (p. 134). Thus, as opposed to the all-too cosy reading of him as some kind of 'fleshy materialist', Deleuze is, in fact, better read 'as a spiritual, redemptive or subtractive thinker, a thinker preoccupied with the mechanics of disembodiment and dematerialisation' (this clearly makes the naturalism very different from its Anglo-American conception). The 'lines of flight' that Deleuze weds thought to as the 'object' of its way of seeing are the result of a thinking that is not other-worldly, but rather 'extra-worldly' (p. 3). The ultimate task for Deleuze is to dissolve the self and become 'imperceptible', to reach the state of being he calls, unwisely in my view, 'schizophrenic'. Hallward also ascribes to Deleuze a 'cosmic pantheism' (it's only through imprecision that Spinoza is described as a pantheist, a reading that Deleuze also follows and that Hallward uncritically adopts oblivious to recent research), in which the logic that informs and steers all of Deleuze's thinking is one in line with a 'theophanic' conception in which, 'every individual process or thing is conceived as a manifestation of expression of God or a conceptual equivalent of God (pure creative potential, force, energy, life...' (p. 4).

In pursuing this 'theophanic' Deleuze, Hallward's study ranges pretty much across the whole extraordinary span of Deleuze's work, with strong chapters on his ontology and on his appreciations of painting, literature, and cinema. Along the way he makes a significant number of instructive insights that enhance our appreciation, for example, at one point he rightly corrects Alain Badiou's erroneous depiction of Deleuze as a vitalist thinker of the animal (it's only the 'becoming-animal' that Deleuze's thought affirms), and at another 
point he provides helpful insights into Deleuze's curious and powerful logic of counter-actualization, that is, his thinking of events, which constitute the real core of his philosophical project (the treatment of the 'phantasm' in Deleuze is excellent; see pp. 94ff.).

There are a number of flaws to the book, however, and some potentially significant lacunae. While Hallward displays on the whole a good appreciation of Spinoza and Bergson in their own right, and is thus able to assess their impact on Deleuze's thought in an instructive and largely reliable manner, this is not the case with his appreciation of Nietzsche. One worry we might have about Deleuze's project is that it submits philosophy to the perpetuation of the ascetic ideal. Deleuze is a metaphysician of a quite classical kind, this much is clear or should be. Now, while he claimed to be unconcerned with 'truth' - he says his concern is with the remarkable, the interesting, the singular, etc. - it also becomes clear from Hallward's study that Deleuze must necessarily wed thought, devotionally so, not simply to an ideal (all thinking is bound up with ideals), but rather with a distinctly ascetic one ('follow the line of flight', 'be true to the body without organs', etc.). Although it is far too simplistic to describe Deleuze's thought as, in essence, ascetic - say in the manner of a philosopher such as Schopenhauer who advocates genuine asceticism - it remains the case that Deleuze's philosophy has something of the dubious air of the ascetic ideal to it (recall that on Nietzsche's account the ascetic ideal entails a hatred of the human and its terrestrial, creaturely conditions of existence, such as transience, sensuousness, the body, and so on). For sure, Deleuze is not in the business of teaching any denial of life; the task is rather to show how it is possible to practise the superior life of the virtual and infinitely creative élan. Nevertheless, this philosophy of the virtual remains, or so it would appear from Hallward's appreciation, enthralled to a practice that is akin to the ascetic ideal. Nietzsche's purification seems to work in a direction completely antithetical to the one Hallward locates in Deleuze, which seeks a complete purification of the bodily and creaturely human (as in the 'body without organs'). In Nietzsche, by contrast, the 'overman' names nothing other than the purification of 'life' from the metaphysics of morality and the morality of metaphysics.

Perhaps Deleuze's departure from Nietzsche is most in evidence in his valuation of Christ. Deleuze valorizes Christ as a figure whose 'masochism' signals the end of the reign of the Father (the super-ego, the impulse of judgment, and so on). This is in marked contrast to Nietzsche who saw in Christ the embodiment of the 'idiot' (in Dostoyevsky's sense) that is devoid of psychological insight and incapable of life-valuation (admittedly, in other places Nietzsche does see enormous value in Christ's attempt to live beyond judgment and to be just). The appeal of Christ for Deleuze is that his incarnation shows, for one time, 'the possibility of the impossible' 
(cited in Hallward, p. 145). In short, it is as if for Deleuze Christ was pointing the way towards 'May '68. It was this event - to be thought in terms of the specific sense Deleuze's gives it, namely, as that which is immaterial, incorporeal, and unlivable ('pure reserve') - that he remained faithful to throughout his life as the event of his time. One worries though that Deleuze's continued valorization of May ' 68 , in which the 'impossible' became possible for a brief time, reveals a thinker who found it hard to engage in severe critical reflection. In fact, one worries that Deleuze's conception of an event as that which is always immaterial and incorporeal - he likens it to 'vapour' - makes it immune from critique. One also wonders whether it gives expression to a moral and political idealism on Deleuze's part. As Nietzsche points out, the danger of focusing on the historical in terms of its 'vapour' aspect (Nietzsche uses this very word), is that one starts speaking in terms of 'a continual generation of phantoms' that hover 'over the impenetrable mist of an unfathomable reality'.

Hallward appears to have no appreciation of what we might call 'the Nietzsche-event' and its significance for philosophy, notably its far-reaching critique of metaphysics and of morality. His conception of Nietzsche, at the few places he proffers it, is distinctly odd. For example, at one point he brazenly declares that, 'Nietzsche allows Deleuze to supplement his empiricist account of the cognitive emergence of the human subject [attained through Hume] with a quasi-cosmological account of the human as an especially anti-virulent form of anti-creation' (p. 63). Not only does such a claim completely misrecognize the identity of Nietzsche's 'overman', it also displays an utter lack of knowledge about Nietzsche's study of the human animal. While it may have its basis in the impoverished account of this issue we find in Deleuze's text on Nietzsche, which accords undue privilege to the Genealogy of Morals, a text that Nietzsche conceived as 'small, polemical pamphlet', this is no excuse for repeating it. It shows a distinct lack of intellectual independence. What is 'quasi-cosmological' about Nietzsche's account of the human animal (say, for example, in the Second Essay of the Genealogy of Morality)? If we describe the human as a form of anti-creation, from what possible place of intelligible thought in the universe is this issued? The description is absurd, and everything in Nietzsche demonstrates this.

The principal complaint Hallward levels at Deleuze's mode of thinking is that it is unable to recognize the importance of 'mediation', so leaving us with an absolute gulf between the virtual (the pure élan) and the actual (fully formed things, states of affairs, and persons). The philosophy of creation turns out to be a philosophy of contemplation. The results of this denigration of the actual, if they are what Hallward claims, are indeed worrying. However, while this point about the lack of a conception of mediation in Deleuze is a criticism well 
worth making, it is made in a fashion that is far too impressionistic. Moreover, Hallward conveniently ignores Deleuze's statement, made in Bergsonism and derived from Bergson, that there remains too much contemplation in philosophy. In a footnote the author makes an important point about 'constitution', and this again merits being developed in properly adequate terms. What Hallward misses in Deleuze, and which strikes me as being highly relevant to his concerns, is his thinking of 'institutions', which ranges from one of his earliest pieces on 'Instincts and Institutions' to his works of 1953 on Hume ('The Cultural World and General Rules') and of 1962 on Nietzsche in which he reads Nietzsche on culture and training. It could be that as his work progressed Deleuze cultivated in himself more and more the tendency, always a feature of his thought from its very beginnings, to visionary metaphysics and at the expense of a philosophy of history and culture, as well as a political theory. But this is a point that requires a proper demonstration, and it is perhaps the chief flaw of Hallward's study that it does not do this. Hallward openly admits to being selective in his reading of Deleuze. However, he is perhaps insufficiently aware of the extent to which this mars the reading he advances in this study.

One further critical point that needs to be made concerns the usage of Bergson in this book. Hallward is tremendously helpful in illuminating the crucial role played by a certain Bergsonism in Deleuze's thinking, but this is done at the expense of not respecting the integrity of Bergson's own project, one that is much less preoccupied with the virtual and that certainly makes no cult of it. It would be difficult to argue that the ontological gulf between the virtual and the actual that Hallward sees as lying at the core of Deleuze's thinking is also at work in Bergson (and I am not convinced the gulf is of the kind and the degree he insists it is). When Bergson's ideas are dealt with in the book they are extracted from the wider context of his elaborate arguments and conveniently made to serve the ends of the book's reading of Deleuze. Bergson's contributions to philosophy merit much more scrupulous attention than Hallward is able to grant them.

Hallward's study seeks to get to the core of Deleuze's thinking, to its heart as it were, and he believes he has found it in this 'theophanic' conception of being. It is only at the very end, however, that he expresses his disquiet over Deleuze's thinking and advances his personal criticisms. In my view more of the study should have been devoted to this task. As it is, his criticisms come across in the wrong way, presented in the manner of, in Hegel's phrase, being 'shot from a pistol'. 